\title{
KNOW WHAT YOU ARE DOING: \\ LEARNING AND TEACHING THEORIES \\ BEHIND THE CLASSROOM PRACTICE
}

\author{
Sugirin \\ FBS Universitas Negeri Yogyakarta (e-mail: sugirin@uny.ac.id; \\ HP: 08122781479)
}

\begin{abstract}
Abstrak: Pahami Tindakan Anda: Teori Pembelajaran di balik Praktik di Kelas. Studi kasus ini bertujuan mengungkap sejauh mana mahasiswa calon guru mampu memberikan alasan atas tindakan kelas yang dilakukan dalam pelatihan bahasa Inggris bagi pekerja industri kerajinan di Kabupaten Bantul dan Kota Yogyakarta. Data tentang tindakan, yang dikumpulkan melalui pengamatan non-partisipan yang didukung rekaman video, dianalisis dengan analisis model Blaxter, Hughes and Tight's (2006), sementara data tentang alasan tindakan dianalisis dengan model Miles \& Huberman (1994: 10). Hasil analisis menunjukkan bahwa mahasiswa calon guru dalam penelitian ini: (1) tidak selalu mampu memberikan alasan yang tepat atas tindakan yang secara pedagogik benar; (2) tidak mampu memberikan alasan atas sebagian besar tindakan yang secara pedagogik tidak tepat; dan (3) memberikan alasan yang berubah-ubah atas tindakan yang secara pedagogik tidak jelas tujuannya. Temuan kajian ini mendukung keraguan Chappell \& Hawke (2003) apakah para guru memahami apa yang mereka lakukan.
\end{abstract}

Kata kunci: studi kasus, teori pembelajaran, praktik di kelas

\section{INTRODUCTION}

One of the requirements for the student-teachers of the English Language Education Department of Yogyakarta State University to join teaching practicum is that they have taken and passed the TEFL Methodology class. Aspects the student-teachers learn in this class are approaches, methods, and techniques of teaching English considered in line with the demands at the time of their emergence and their relevance to the current practice. The student-teachers, after the teaching practicum period, especially after Teaching Practicum II, are expected to have more understanding of the problems in the field so that the performance in the learning and teaching practice conducted constitutes the accumulative result of the creativity and innovation due to the demand from the field. However, creativity and innovation should not be completely detached from the understanding of theories, assumptions, or beliefs.

As Chappell \& Hawke (2003) noted, the emergence of various learning and teaching methods implemented in voca- 
tional education program was due to the development as a response to the community demands, but they were not coupled with well-conceived theoretical bases or mature concepts. Chappell \& Hawke (2003) state that teaching and learning practice needs rationales as its theoretical bases. This is in line with one of the principles of communicative language teaching that teachers should know what they are doing (Morrow in Aslam, 1992), in the sense that whatever action a teacher takes should have an underlying assumption or theoretical basis. At least, according the teacher's own experience, the action taken proves effective in the development of one or more of the learners' cognitive, psychomotor, or affective learning domains. In addition, Applebaum (2007) asserts that in communicative English language teaching, every teacher's activity must have a clear communicative purpose. Hence, a teacher applying a communicative approach to teaching must be able to provide a reason for taking an action.

In a teaching simulation conducted by the fourth semester student-teachers in a TEFL Methodology class, a number of the student-teachers showed actions in the teaching activities, such as moving from left to right or the other way around in a standing position, which did not seem to have any clear purpose. From an informal observation, a similar phenomenon happened to a teacher who had served for over eight years, who joined the Teacher Professionalism Education and Training (PLPG). This teacher held a board marker in his hand and kept playing with it while talking to the class during the peer teaching practicum. In the case of the student-teacher, the left-right movements might have been a spontaneous reaction to her tension or nervousness. This might be gone as she managed to control herself. However, it would be misleading if she did it because of a mistaken concept that a teacher must not stay at one spot and had to move places during the teaching and learning process. In the case of the teacher playing with the board marker, the tension and nervousness might have come from the presence of the two examiners watching him while he was teaching his peers. However, as he had served or taught for over eight years, the hypothesis that playing with an object while talking to the class during the teaching process would be gone as he managed to overcome the tension or nervousness was questionable.

While a teacher who had served for over eight years still performed such a pedagogically unjustifiable action, it was assumed that there could be numerous phenomena in the student-teachers' classroom actions with or without clear theoretical reasons. It is, therefore, worthwhile revealing these phenomena through an observation of their classroom practice through a research study. This study aimed at revealing to what extent the student-teachers participating in the study were able to provide theoretical reasons underlying classroom actions they took during the English language training sessions they conducted for the staff of the craft industries in the area of Kasongan and Krebet (Bantul Regency), and Kotagede (City of Yogyakarta). 
In accordance with the Curriculum of the English Language Education Study Program of Yogyakarta State University (2002), one of the requirements for the students to join the teaching practicum is that they have to have taken and passed the course of TEFL Methodology. In this course the students learn approaches, methods, and techniques in teaching English and related theoretical aspects. Hence, in the post teaching practicum period, students are targeted to be able to demonstrate acceptable teaching performance supported by a good understanding of learning and teaching theories.

Chappell \& Hawke (2003) express concern about the need to understand theoretical reasons underlying increased diversity of teaching and learning methods in response to immediate needs within vocational education programs. However, these methods have not been accompanied by any theoretical or conceptual underpinning. To Chappell \& Hawke (2003), instructional practice needs rationales as theoretical bases, while Richards and Lockhart (1996) believe that the teachers' activities in the classroom are based on their knowledge and way of thinking. This is in line with the principle that teachers should know what they are doing (Brown, 2001) - in the sense that whatever actions teachers take must be based on a theoretical basis. At least, from their own experience, the actions they take have proved effective in developing the learners' learning domains: cognitive, affective, and psychomotor, or in developing the teachers' own basic competences. Understanding learning and teaching theories is also the demand of the Act of the Republic of Indonesia No. 14 Year 2005 on Teachers and Lecturers, Article 10, which says: (1) Teachers' competences as intended in Article 8 include: pedagogical, personal, social, and professional competences, obtained through professional education.

Applebaum (2007) asserts that in the communicative English language teaching, the teaching must be purposeful. Everything is conducted with communicative intent. Thus, teachers applying communicative approach to the English language teaching must be able to provide rationales for the actions they take during the teaching and learning process. Actions without clear purposes are useless and can even distract the learners' attention. As an example, asking the learners to read a text aloud before they understand the content violates the reading theory. Comprehension, which is considered a problemsolving process, is an effort to search for meaning which is not achieved through reading aloud (Barry, 2011:1). Barry argues that when scribes began to add spaces between words, they changed the whole neuropsychological process of reading. No longer did a solitary reader have to slowly and painfully extract information from text, mumbling to himself as he did so. With the task of word separation now assigned to the scribe rather than the reader, reading became silent, rapid, effortless and meditative. In addition, Gardiner's (2001:2) study showed that students trained in silent reading developed better skills in reading comprehension, 
spelling and vocabulary, and scored high in standardized reading tests.

If teachers do not understand this information, not only is teaching inefficient, but it will also give an impression on the learners that reading aloud is a means to text comprehension. Therefore, the Danish Delegation of the NATO Training Working Group (2003) state that competent teachers do not only master the subject at which they major, but they must also master a wide range of knowledge about learning theories reflected in the classroom practice. In the same spirit, Tennyson (2010:1) asserts that educators need to clearly propose and define their own theoretical foundations when engaging in the design of effective learning environments.

Article 25 (4) of the Government Regulation No. 19/2005 on the National Education Standard explains that graduates' competences include affection, knowledge, and skill. It means that instruction and evaluation must develop competences related to the affective, cognitive, and psychomotor domains. Hence, any teaching and learning activity that is not related to the development of those three domains has no clear theoretical underpinnings.

The teachers' need for clear theoretical underpinnings has also been proposed by Madya (2002:16) who states that the teacher's knowledge and thoughts give frameworks or schemes that guide the teacher's actions. In this regard, Richards (1996:30), quoting Feiman-Nemser and Floden, assert:

"Teaching cultures are embodied in the work-related beliefs and knowledge teachers share - beliefs about appropriate ways of acting on the job and rewarding aspects of teaching, and knowledge that enables teachers to do their work."

This is supported by Hooper (2008), who claims that people's beliefs affect their actions. Similarly, Hiebert, Gallimore, and Stigler (2002:6) delineate that practitioner's knowledge is linked with practice. This knowledge is useful for practice, precisely because it develops in response to specific problems of practice.

\section{METHOD}

The research study reported in this paper used the case study approach. The approach was chosen deliberately on the basis of specific attributes to be found in the case - attributes that were particularly significant in terms of the practical problem or theoretical issue that the researcher wanted to investigate (Denscombe, 2007: 39). This study emphasized processes rather than outcomes and depth rather than breadth the depth of the information in regard to the reasons or theories behind the actions the student-teachers took in the teaching and learning process.

The subjects of this research were 20 student-teachers of Semester VIII of the English Education Department, the Faculty of Languages and Arts, Yogyakarta State University, who were taking the TEFL Program Development class in 2009. These students were implementing the English language teaching program designed for the staff of the craft industries in the area of Kasongan and 
Krebet (in Bantul Regency), and Kotagede (in the City of Yogyakarta). In all these locations, the training was conducted twice a week, from 07.30 to 09.00 in the evening.

The data of this study consisted of the actions the student-teachers took during the teaching and learning process in the language training program mentioned earlier and the reasons for taking the actions. As the data collected were qualitative in nature, this research study was a qualitative one. Following Patton's (1990:14) suggestion, the main instrument in this research was the researcher himself. In order to find the student-teachers' understanding of the theories of, or rationales for, taking the actions during the teaching and learning processes, in-depth interviews were carried out on student-teachers individually as well as in groups. As reference for the interview, the researcher used observation notes and audio-visual records on the teaching and learning processes in the three locations of the English language training.

In this study, actions noted during the observations to be included as data were not randomly selected; they were selected on the basis of known attributes (Denscombe, 2007:39). The selection of the actions followed Blaxter, Hughes and Tight's (2006) model of analyzing observations. Basically, the analysis model consists of summarizing episode and forming themes/categories. The characteristic of the model was that it allowed the researcher to be selective and partisan in deciding which actions would be included in the body of the data. Justifiability and variability of the actions became the criteria for the selection. For example, a running well episode, in which nothing unusual happened, might be excluded from the data. In contrast, episodes in which unjustifiable actions occurred would most likely be included in the data. This was the researcher's partisanship or bias which Blaxter, Hughes and Tight's (2006) observation analysis model tolerates. However, the researcher focused on which actions, not whose actions, would be included in the data.

In analyzing the interview data, the reasons for taking actions in the teaching and learning process, the researcher applied Miles and Huberman's (1994: 10) interactive data analysis model consisting of three interrelated components - data reduction, data display, and inference drawing/verification. These three activities were also related to the data collection activities so that they constituted cyclical and interactive processes. Following each learning and teaching session in the training program, the researcher spent part of the next TEFL Program Development class time to interview the students whose actions were noted as relevant data. The students were asked to give reasons why they had taken those noted actions during the teaching and learning process. The action was revealed from the notes or spotted from the video replay. Each of the students recorded in the observation field notes was told or shown what action s/he had taken. S/he was asked to provide reasons for the action taken. When a student did not give a satisfactory answer, the other 
students were invited to contribute to the class.

The researcher then classified the actions and the reasons following the classification criteria of justifiability of actions based on the theoretical underpinning in pedagogy (Kivela, et al., 1995). This way, the researcher was able to see whether the class as a group had taken pedagogically justifiable actions in their teaching and learning process. In other words, the researcher expected to be able to conclude whether these student-teachers knew what they were doing.

As can be seen from the data collection procedure above, in order to ensure the validity, this research study used a method triangulation. While the student-teachers were invited to verify the data, peer debriefing was conducted by asking a colleague who was knowledgeable about qualitative research to examine the findings and ask questions or make clarification on any information related to this study. This way, it was expected that this research study would be meaningful to others as well as to the researcher himself.

\section{RESEARCH FINDINGS}

With twenty student-teachers participating in this study, there was a long list of actions recorded from the observation field notes as well as the video replay. However, due to space limitation, the findings reported in this paper are those representing the criteria of justifiability and variability of the data (of the actions and the reasons) mentioned earlier. The selection of research findings to be included in this report (following Blaxter, Hughes and Tight's [2006] selection model) was also partisan. However, these findings are expected to give a comprehensive picture of what the student-teachers had done in their efforts to facilitate the training participants to develop their English mastery, especially their speaking competence, and the reasons for what they had done.

The research findings, in general, show that the student-teachers in this study: (1) were not always able to provide proper theoretical reasons for theoretically justified actions; (2) were unable to provide theoretical reasons for most of the theoretically unjustfiable actions; and (3) provided inconsistent reasons for pedagogically ambiguous actions. These findings can be elaborated as follow.

- The student-teachers were not always able to provide proper theoretical reasons for pedagogically justified actions

The first striking phenomenon attracting the researcher's attention was the presence of under-five-yearold children in the classroom. These children were sitting either next to the mother or the sister joining the training program. The student-teachers did not seem bothered with their presence. Once in a while they even give these children some candies or other small nibbles. When asked why the student-teachers allowed the children to join the class, they said that there was no adult at home who could accompany them (from 07.30 to 09.00 in the evening). This phenol- 
menon occurred both in Kasongan and Krebet.

The second phenomenon the researcher noted was that on every day of the course there were always two or three student-teachers presenting new materials before the tutorial session was conducted. When asked why this kind of presentation was conducted, the student-teacher acting as the academic coordinator said that when there were a number of topics to be presented, they set tasks to two or more presenters. The arguments were: (1) each presenter could focus on one or two topics of his/her choice with thorough preparation; (2) different presenters with their own styles would attract the participants' attention and avoid boredom; (3) student-teachers had more opportunities to build a positive image and relationship with the participants, which would be further developed during the tutorial session.

The third phenomenon the researcher observed was that after the lecture or presentation session, the training coordinator always divided the participants into several groups for tutorial and language practice. When questioned why she did so, she argued that there were six to ten student-teachers working on each meeting day so that they ought to be given opportunities to help the participants. Dividing the class into groups enabled each student teacher to be involved in the tutorial session.

The fourth remarkable phenomenon was also spotted in the language training conducted for the silver craftsmen and souvenir shop assistants in Kotagede, City of Yogyakarta. The student-teachers conducting the training did not only make a comprehensive preparation for the program, but they also printed the materials in the form of a colorful booklet. When asked why they went as far as having the training materials printed and bound, they proudly said that they did it because they managed to get funding from several sponsors. One of the sponsors was a local printing company. To show their accountability to the sponsors for their contribution, they also put the identities of the sponsors on the cover of the booklet.

- The student-teachers were unable to provide theoretical reasons for most of the pedagogically unjustifiable actions

The first student-teacher presenting the topic on greeting moved so fast in her presentation that a female participant whispered "Gak ngerti, Bu!" (I couldn't understand, Miss!), while a male participant explicitly shouted "Terlalu cepat, Bu!" (Too fast, Miss!). The student-teacher, who had good pronunciation and confidence standing in front of the class, must have heard the complaints but did not make any adjustment on the rate of the speech nor that of the presentation. She walked approaching the participants in the middle and the back seat rows, but did not make any comment on, or respond to, the participants' complaints. She seemed enjoying what she was doing and con- 
tinued with her speed of presentation. When asked to provide a reason for not changing the speed of her presentation, she said she spoke naturally with her normal speed. She could not speak slowly; otherwise, she might miss points she wanted to say. She said she heard the complaint from the male participant, but the others seemed comfortable with her speed so that she did not feel the need for changing her rate of presentation.

The second, in most of the presentation of the new materials the student-teachers used the PPP (presentation, practice, and production) technique. However, in a speaking session, a female student teacher distributed a sheet containing a dialogue to the class and asked a pair of participants to practice the unrehearsed dialogue in front of the class. Consequently, the participants did not seem confident and had problems practicing (or, rather, reading) the dialogue. When asked why the dialogue was not presented by models (tutors or participants who had good pronunciation) before asking the participants to practice the dialogue, the student-teacher said that it was to encourage the participants to try to speak the language before a model was given. However, a correct model was not given, and further practices were done by the students in groups.

Another point of concern was related to the high proportion of the use of Indonesian as the language of instruction in Krebet. When asked for the reason, the student-teachers were afraid that the participants who were mostlybatik course instructors would not understand the essence of the lesson dealing with teaching techniques.

- The student-teachers provide inconsistent reasons for pedagogically ambiguous actions.

The first action puzzling the researcher was a "Hello!" greeting in the middle of the session spoken by a female student-teacher to the class to which the class responded "Hi!" The same greeting and response were repeated three to four times during one session. The next day, when the researcher asked for clarification, the student-teacher said that the greeting "Hello!" was meant (1) to maintain the participants' attention; (2) to keep the class alive; and (3) to check the class's automatic response to the prompt previously understood and agreed upon by the participants and the student-teacher concerned.

Another female student-teacher distributed an approximately-100word reading passage at the beginning of the session and asked one of the students to read the text aloud. When asked about the reason for instructing the participant to read the text aloud, she argued that, after reading aloud, the students would answer questions related to the text. When asked if the reading of the text aloud was meant to comprehend the text, she said "Yes." When asked for confirmation whether she could comprehend a text by reading it aloud, she started meandering, saying "Maybe. Maybe the other students will 
understand the text and know how to pronounce some difficult words in the passage."

\section{DISCUSSION}

The three points of findings abovementioned may be illustrated as follows.

The Student-teachers were not Always Able to Provide Proper Theoretical Reasons for Pedagogically Justifiable Actions

In regard to allowing two or three participants to attend the training with under-five children in the classroom was a wise decision, a service to the participants' need. Without bringing the children to the classroom, the mother or the sister concerned would not have been able to join the training. This indicated that the student-teachers were sensitive to the participants' problem and need. Despite their inability to express it explicitly, these student-teachers were able to accept the participants as whole-persons (with their individual problems and needs). In Zimring's (1999:106-06) words, they have applied the person-centered approach which is essentially a person-to-person relationship between the facilitator and the learner.

Appointing two or more presenters in a session, when proper preparation was made, indeed could attract the participants' attention and avoid boredom as each presenter could demonstrate his/her expertise and specialty. Besides, the regular presence of almost all the student-teachers in each session had to be meaningful for the participants. The more student-teachers play- ing roles, the more respect and appreciation they received from the participants.

When dividing the class into groups was merely due to giving all studentteachers opportunities to be involved in the activities, the coordinator had not given enough thoughts to the participants whose welfare should have been the main concern in any action taken. The action itself was justified but the reason for taking it was partial as it had not considered the participants' need. Not all the participants always understood the presentation thoroughly or were ready to do oral language practice in front of the class after the presentation. The group work was actually meant for clarification of the presentation and preparation for speaking practice as the most important goal of joining the training was to develop their speaking ability. Speaking in front of the class could be a fear for many. By giving the participants an opportunity to work on language practice in groups the student-teachers already practiced a therapy on the students who feared to speak in public. In a group tutorial, a participant who was not ready to speak could just observe and listen to the others. This participant could say something when $s /$ he was ready. Whenever s/he had to say something, assistance would always be given by the tutor. Her/his fear slowly disappeared and $\mathrm{s} /$ he felt comfortable participating in the language practice and other group work. After several sessions, this participant had courage to speak in the group and, finally, had confidence in reporting the result of a group discussion 
to the class. Despite the inability to theorize why they asked the participants to work in groups before practicing speaking in front of the class, these student-teachers already practiced the fear extinction theory (Walker, 2011). By working in groups, basically the participants were put in a situation of relaxation which set no immediate task or demand until they were ready for it. This way, the participants' fear was slowly removed and turned to confidence. In a similar setting, Yahaya's study (2004) concluded that, apart from fear extinction, group counseling combined with SQ3R reading technique also improves students' study habits and, hence, improve performance.

Concerning the question why the student-teachers providing language training for the silver craftsmen and souvenir shop assistants in Kotagede, the answer did not touch upon its relevance to the teaching and learning process at all. They did not even mention its possible impact on the impression of the participants on the course preparation. While proving accountability to the sponsors was required, giving the participants impression that they were serious about the training, as shown by the handy booklet each participant had received, was also important. The most appropriate answer was that the booklet could be a handy reference for both the student-teachers and the training participants. Both parties could read it and make necessary preparation before each session. In the teaching and learning process, the participants did not have to copy any text, but could concentrate on their class- room participation. Despite its quality which might still need improvement, the ready-made materials could faciletate the teaching and learning process. As Richards (2001:251) claims, instructtional materials are a key component in most language programs.

\section{The Student-teachers were Unable to} Provide Theoretical Reasons for Most of the Pedagogically Unjustifiable Actions

In relation to the student-teacher who did not modify her speed of presenting the material on greetings, despite the participants' complaints, clearly she did not try to provide the participants with comprehensible input (Krashen, 2003), the language they could understand, i.e. information spoken in a rate of speech they could follow. As greetings are usually given at the beginning of such a language course, she seemed to assume that the course participants were familiar with the materials presented. She seemed to forget that some of the participants were complete beginners. Hence, to some, not only did she speak fast, but she also moved fast from one form of greeting to another, assuming that the participants already knew the items presented. In this regard, this student-teacher had not come to understand the need to base teaching on the learner's need and background knowledge, despite all considerations the academic coordinator and team members had taken to include greetings as one of the topics of presentation. In this context, many participants still needed thorough presentation, practice and production on greetings, although 
some might only need refreshing or confirmation on the context of use. For example, most participants were still confused with the use of "good evening" and "good night." While the use of "good evening" can be easily defined by time (06.00 p.m. to 12.00 midnight), the use of "good night" is much dependent on context (parting and no further encounter before bed time) and may cover the range of time roughly from $06.00 \mathrm{pm}$ to 06.00 a.m. In this regard, this student-teacher seemed to neglect the importance of comprehensible input (Krashen, 2003).

Asking the participants to practice (read) a dialogue in pairs before a model was given was clearly non-procedural. It could be threatening and against the idea of using group work to prepare the participants for class practice or individual presentation. At this stage the student-teachers should present the new language in a meaningful context using real objects or demonstration of specific behaviors and language patterns used in day-to-day experiences. Only then could practice be carried out.

Related to the use of mother tongue, the use of Indonesian as the language of instruction, Simon (2009) suggests that the mother tongue should be used with 'clearly-defined circumstances and in the carefully crafted activities'. The true reason is that there is a tendency for teachers starting out to use the mother tongue as they do not know of any other ways to do the same thing. It is also seen as an easy way out, which more often than not can be an inaccurate way, and teachers can fall into the trap of using the mother tongue more than is healthy for both the students and the teacher.

\section{The Student-teachers Provide Incon- sistent Reasons for Pedagogically Am- biguous Actions}

The contract of agreement between the student-teacher and the participants on the use of a "Hello!" greeting with a "Hi!" response was indeed a creative effort to maintain the participants' attention, to keep the class alive, and to check the class's automatic response to the prompt given by the student-teacher. Such a contract of agreement was also used by Culbertson (2001) to avoid boring lectures.

In giving a reason for instructing a participant to read the text aloud at the beginning of the reading comprehension session, the student-teacher appeared to assume that by reading the text aloud the reader would be able to comprehend the text. This may be inferred from her argument that after reading the text aloud the participants would be asked to answer questions related to the text. This indicated that, in her opinion, reading the text aloud would entail comprehension, which might not be in line with most reading theorists'. According to Taylor (2006: 3-4), "The visual path is a route to meaning, the phonetic path a route to remembering". Reading a text aloud may aid remembering, but it is the silent reading which leads to a reader's understanding of the text. Taylor further asserts that during oral reading (reading aloud) attention must necessarily be primarily focused on perceiving and recognizing print (visual input 
process) and producing acceptable oral expression. Comprehension is, therefore, necessarily de-emphasized, while saying words during oral or silent reading does slow down the reading process and can become habitual and overly depended upon if over-emphasized. While Barry (2011:1) argues that comprehension is achieved through silent reading, not reading aloud, Gardiner's (2001:2) study showed that students trained in silent reading developed better skills in reading comprehension, spelling and vocabulary, and scored high in standardized reading tests.

Reading aloud is welcomed in a reading class when it is done in the proper context and manner. For example when a teacher asks a question in which the answer or part of it is in the text, then the student will naturally answer the question by reading the text aloud. When the teacher asks a question such as "How do you know that John did not have much money?" the student may answer: "In the third line of the last paragraph, John said 'I'm broke.' The expression 'I'm broke' here means that John had no money."

\section{CONCLUSION}

Being able to provide rationales for actions taken is important for teachers as the actions taken are generally based on the beliefs on or understanding of the concepts or theories underlying the actions. Despite their general ability to manage the teaching and learning process, the student-teachers in this study still performed actions that were not fully justifiable. Besides, the classroom actions they took were not always based on the firm beliefs or rationales. The implication is that further guidance or a reminder is still needed for these student-teachers to ensure that they can eliminate unjustifiable actions in their future teaching performance. In addition, they might need to review the materials of TEFL Methodology and other related resources so that they would be able to keep reflecting on, improving, and updating, their learning and teaching practice.

\section{ACKNOWLEDGEMENTS}

I would like to extend my appreciation to the Editorial Board of Cakrawala Pendidikan, especially Prof. Dr. Burhan Nurgiantoro, for the inclusion of this article in the current publication, and to the Editors, particularly Mr. Suharso, M. Pd. for the invaluable suggested improvement. My thanks also go to the Editorial Staff for their patience and prompt service so that this article can be published in the present edition.

\section{REFERENCES}

Applebaum, B. 2007. "Communicative Language Teaching: Theory, Practice, and Personal Experience". Mandiri, Volume 9, No. 4, April Juni 2007.

Aslam, R. 1992. Aspects of Language Teaching. New Delhi: Northern Book Centre.

Barry, E. 2011. "Silent Reading". Northcoast Journal, the Journal of Humboldt Country. California. 
Chappell, C. \& Hawke, G. 2003. 'An industry-led VET system: Report 7 - Integrating report' OVAL Working Paper WP03-07. OVAL Research. Sydney: University of Technology.

Culbertson, H. 2001. Teacher-student Learning Contract. Bethany: Southern Nazarene University. From http://home.snu.edu/ hculbert/contract.htm, accessed 25/09/2009.

Gardiner, S. 2001. "Ten Minutes a Day for Silent Reading". Educational Leadership. October 2001. Volume 59. Number 2.

Hooper, D. 2008. "How Do Your Feelings, Values, and Beliefs Affect Your Actions?" The Houston Home Journal. September 2008.

Kivela, A.et al. 1995. "Towards a Theory of Pedagogical Action". Seminar Handout. From http://wwwedu.oulu.fi/homepage/kkttpp/yptr/toward.htm, accessed on 22/11/2010.

Krashen, S. D. 2003. Explorations in Language Acquisition and Use: The Taipei lectures. Portsmouth, NH: Heinemann.

Madya, S. 2002. “Eksplorasi Keyakinan Guru-guru Bahasa Inggris di SLTP Kota Yogyakarta". Laporan Penelitian, Universitas Negeri Yogyakarta.
Miles, M. B. \& Huberman, A. M. 1994. Qualitative Data Analysis. Beverly Hills: Sage Publications.

Patton, M.Q. 1990. Qualitative Evaluation and Research Methods. Second Edition. Newbury Park, London: Sage Publications.

Peraturan Pemerintah Nomor 19 Tahun 2005 tentang Standar Nasional Pendidikan. Lembaran Negara Republik Indonesia Tahun 2005 Nomor 41.

Richards, J.C. 2001. Curriculum Development in Language Teaching. Cambridge: Cambridge University Press.

Richards, J.C. \& Lockhart, C. 1996. Reflective Teaching in Second Language Classroom. Cambridge: Cambridge University Press.

Simon, T. 2009. Review of Using the Mother Tongue Making the most of the learner's language by Sheelagh Deller \& Mario Rinvolucri, Delta Publishing/English Teaching Professional, 2002.

Taylor, S.E. 2006. Fluency in Silent Reading. New York: Taylor Associates/ Communications, Inc.

Tennyson, R. D. 2010. Historical Reflection on Learning Theories and Instruc-tional Design. Contemporary Educational Technology, 2010, 1(1), 1-16 1. 
Walker, D. L. et al. 2011. Facilitation of Conditioned Fear Extinction by Systemic Administration or IntraAmygdala Infusions of D-Cycloserine as Assessed with FearPotentiated Startle in Rats. The Journal of Neuroscience.

Yahaya, L.A. 2004. "Effects of Group Counseling and SQ3R on the Students' Study Habits of Secondary School Students in Ilorin". Journal of Educational Research, Vol. 3, No. 1.

Zimring, F. 1999. Carl Rogers (19021987). Paris: Unesco, International Bureau of Education. 